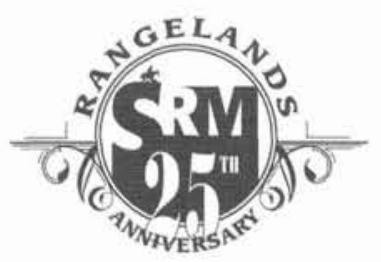

\title{
Rocky Mountain Woolies: Raising Sheep in the New West
}

\author{
By David Bradford, Justin McConkey, Robbie Baird LeValley, \\ Larry Allen, Ross Allen, Brian Farmer and Joe Sperry
}

$\mathrm{D}$ omestic sheep - the very mention of these words conjures up a wide variety of images for the American public. This timid, wooly critter is able to evoke strong emotions ranging from affection to loathing. Why? Whatever the reason, whenever people encounter a flock of sheep the experience often evokes a strong response. This seems especially true on public lands.

Today recreationists and other visitors to National Forests and Bureau of Land Management (BLM) lands still encounter bands of sheep in many parts of the western Unites States. When visitors meet a flock of sheep they usually respond in one of several ways - they are awe-struck with the ambiance of the pastoral setting, aggravated with the inconvenience of making their way through several thousand bleating animals or offended by the sight of thousands of "hooved locusts destroying the land."

What effects do sheep really have on the land? We would like to dis-

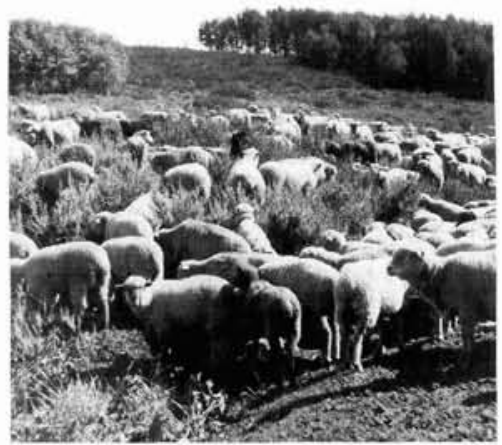
cuss sheep grazing in the modern West, specifically in Delta County, on the Western Slope of Colorado - how it is practiced, how it affects the land and what impacts it has on our society.

\section{History of Sheep Grazing in Delta County}

Domestic sheep were introduced to North America, when the Spaniards came in the fifteenth century. However, sheep were not widespread in the West until the latter half of the nineteenth century. According to the History of Agriculture in Colorado sheep raising in Colorado began and remained slow until the 1880's.
In 1880 there were 110,000 sheep in the state; by 1886 the numbers had increased to 2 million. Cattle numbers increased in a similar fashion during this period. Conflicts between sheepmen and cattlemen began almost immediately. The basis of their conflict was competition for the range resources. At that time the range was open and

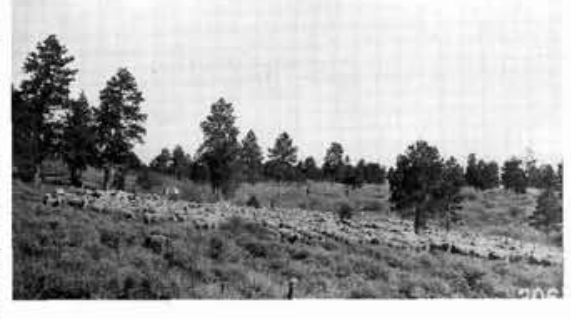
grass and water were free. The conflicts became deadly. Sheep, cattle, property and even human lives were destroyed as these conflicts escalated.

The Western Slope of Colorado officially opened to settlers in 1882, after the Ute Indians were moved to reservations in Utah and southern Colorado in 1881 . The earliest settlers brought primarily cattle and horses. As increased numbers of stock growers competed for the range conflicts developed.

By 1890 a group called the Cattle Growers Protective Association was formed. They operated mostly in secret and became known as "the Night Riders." They tried to intimidate the unwanted sheepmen, but resorted to beating and killing to keep sheep from using the ranges of Delta, Mesa and Montrose counties.

The national recession of 1893 , which affected Colorado especially hard and was known as the "Silver Panic of 1893," caused many cattle growers to go out of business. At least one rancher in Delta County began raising sheep as a result. Enos Hotchkiss began raising sheep in mid-1890, and the family ranch is still raising sheep and cattle. For the most part, however, sheep continued to be unpopular and cattle growers continued trying to keep sheep out of the local area. 
In 1915 the Forest Service permitted the first sheep on the Gunnison National Forest. The Night Riders attacked this band of sheep in the Oh-BeJoyful Creek area above Crested Butte. They tied up the herder and drove the sheep off a cliff, killing 200.

Economic incentives due to the demand for wool during the First World War moderated many ranchers' opposition to sheep. In 1917, the Forest Service began permitting larger numbers of sheep. Sheep numbers grew and by 1940 there were over 150,000 head of sheep permitted on the Grand Mesa, Uncompahgre and Gunnison National Forests. Today there are 28,000 sheep permitted on the three national Forests.

\section{Sheep in Delta County Today}

In January, 2000 there were nearly 67,000 sheep producers in the United States raising approximately 7 million sheep and lambs. In Delta County there are 46 producers raising 9,000 ewes. These producers include many small farm flocks and a number of larger full-time sheep producers. Herd size for fulltime sheep producers in Delta County varies from 1,000 to 3,600 ewes.

The breeds vary though most producers use a cross of breeds including Columbian, Ramboullet, Targhee and Polypay. These breeds were developed to produce both wool and meat. The wool from these breeds is a medium to fine grade wool with a $21 / 2$ to $31 / 2$ staple length.

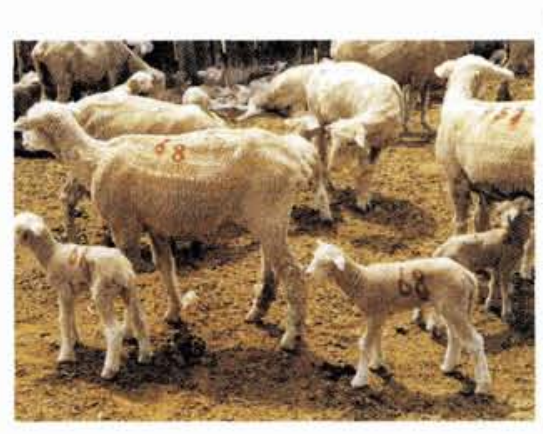

\section{The Cycle of Raising Sheep}

Raising sheep begins with breeding. Ewes are bred in the fall in October/November. Most sheep producers place 4 bucks per 100 ewes, though some will use 2 or 3 bucks if they are especially aggressive. Lambs are born in April following a five-month gestation period.

Most producers strive for a 21 day breeding/lambing season. Breeding usually takes place in the valley on irrigated pastures. Sheep need to be in good

\section{Why raise livestock?}

People raise livestock because it provides an economic opportunity from lands that are generally less productive or incapable of p rod u c ing other goods.

Like many areas in the West, Delta County, Colorado, has a highly varied landscape. The county is essentially a "high desert" - the Uncompahgre Basin, surrounded by the Rocky Mountains. There are three rivers- the Uncompahgre, the Gunnison and the North Fork of the Gunnison, that drain into the Basin from the mountains. The variety of landscape features provides magnificent scenery but also limits economic opportunities. The variation in the terrain also creates great differences in annual precipitation patterns and amounts. Though precipitation falls fairly evenly throughout the year, amounts vary significantly depending on the specific location on the landscape. The river bottoms are the most productive lands, even though they receive 8 inches of moisture or less per year, as they are sub-irrigated by the rivers. The mass of the basin is salt desert shrub land, sagebrush-covered mesas, juniper woodlands, or oakbrush slopes and receives 15 inches of moisture or less. The highest mountains receive from 30 to nearly 40 inches. The limited precipitation means that irrigation is a necessity in order to sustain community and agricultural activities. Livestock production allows these areas to be used for economic activity without altering the natural landscape to better suit human needs and desires. Sheep are especially well suited for many of the different landscapes in the Uncompahgre Basin. Even the Tabuache Utes were raising sheep in the Uncompahgre Basin in 1880. The Annual Report of the Commissioner of Indian Affairs to the Secretary of the Interior for the Year 1881 lists 9,100 sheep at the Los Pinos Agency on the Uncompahgre River. When properly managed these lands can be used for livestock production on a sustainable basis. 
body condition to assure successful breeding and a good lamb crop in the spring.

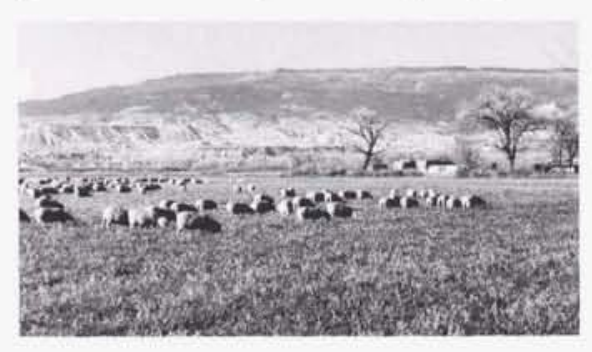

As breeding is completed, the sheep are moved out to the winter ranges. In Delta County the winter ranges are located in the lower valley on the salt desert, an area that most of the locals call the "adobies." The sheep stay on these winter ranges from November through March. As spring approaches the sheep are moved back to the home ranch.

The wool from the ewes is shorn just prior to lambing. The wool is shorn by shearing crews who work Australia, New Zealand, the United States and Great Britain. Lambing takes place in April. As the lambs are born, the ewes and lambs are moved onto irrigated pastures on the home ranch. When lambing is completed, the sheep are moved to spring ranges, usually onto higher elevation private or BLM lands.

As summer approaches, the sheep move onto the national forests. The sheep graze on the national forest from June through September. When the sheep come off the forest, the lambs are weaned and trucked to a feedlot, usually in eastern Colorado. The ewes will stay on private pasture in the mountains through early fall, when they are trucked or trailed down the valley to irrigated pastures or crop residues, where the cycle begins all over again.

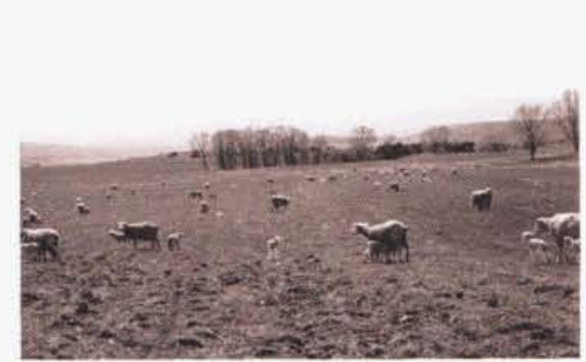

\section{Lambing}

Nearly

all

lambs in Delta County are born in sheds and not on open range. Most ewes produce twins and some triplets. Lambing success generally runs 150 $200 \%$. The ewes and lambs usually move from lambing sheds onto irrigated pastures near the home ranch for several weeks, before moving on to the range.
Lambs remain with ewes until they are weaned, usually around mid-September. They are then trucked to a feedlot. Lambs are about 6 months old at weaning and shipping weights range from $90 \mathrm{lbs}$ to $115 \mathrm{lbs}$. (The variation in lamb weights is mostly due to forage conditions during the year and the number of twins produced.) Ewes with twins will raise lighter lambs. Lambs in western Colorado grow faster than in almost any other area in the United States. There is even a class of lamb on the national market summary called the "West Slope Lamb."

\section{Wool Production}

Sheep are shorn once a year -in the spring just prior to lambing. Delta County sheep produce about 10 pounds of wool per sheep at the spring clip. Current wool prices are about 50 cents per pound. This represents about 10 percent of the total income produced from the overall operation. Sheep in the United States are raised for both wool and meat. American wool and sheep now compete in the world market with the result that current lamb prices have fallen to around 55 cents per pound.

\section{Management}

Raising sheep is a labor-intensive operation. The sheep are cared for continuously by a

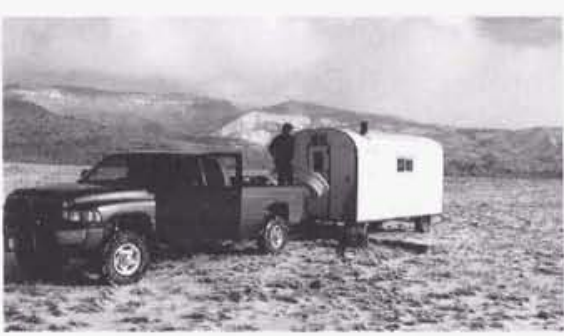
herder. The herder generally rides horseback and is assisted by both herding and guard dogs. A camp tender, who moves the herder's camp and keeps him supplied with food, water and other necessities, supports the

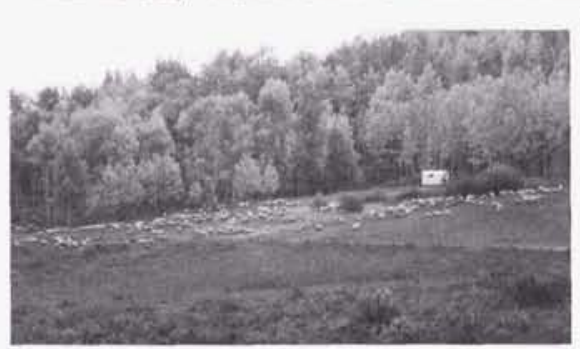
herder.

The sheep graze using a "onceover" strategy meaning they graze each area one time during the grazing season. The bands run from 900 to 1,000 ewes. With multiple births this means that most herds of sheep have around 2,500 to 3,000 animals. Sheep are grazed in 


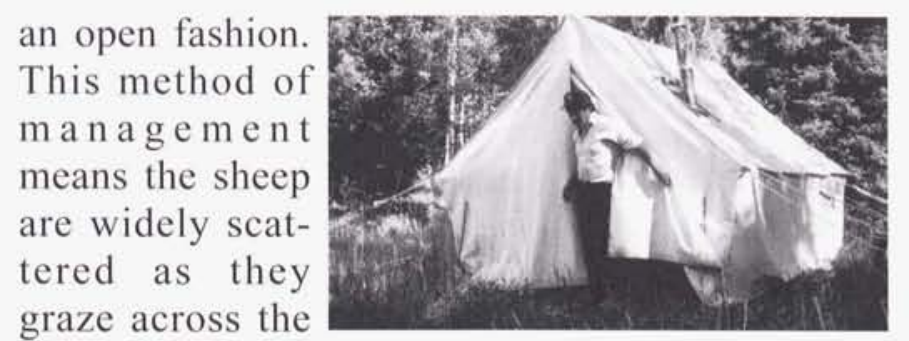

landscape. Open

herding prevents trampling damage to vegetation and soils.

The herder stays with the sheep sleeping nearby in either a "herder-wagon" or a wall-tent, depending on access to the area. The camp is moved frequently, ranging from every day to every 10 days, depending on the area and forage conditions. This means that a single area could be grazed for up to ten days in a single year. Sheep are bedded in a different location almost every night.

For grazing on BLM and national forest rangelands, the sheep producer meets with the rangeland specialist to develop plans for grazing their allotment each year. This plan includes the season of use, camp locations, length of time at each camp and monitoring the effects of grazing. The plans are based on plant physiology, plant responses to grazing, the needs of the sheep, wildlife needs and other multiple use concerns. Proper planning provides for the maintenance of healthy vegetative communities, minimizes animal health problems, reduces predator losses and maintains economic viability of the operation. On-the-ground implementation of these grazing plans are key to the success of the grazing strategy. Properly implemented sheep grazing is ecologically sustainable, improperly implemented it can be damaging to the environment.

\section{Health Issues}

Sheep are prone to a variety of diseases. In Delta County the primary diseases are foot rot and mastitis. Good management of the herd and land minimizes health problems.

\section{Predators}

Sheep are easy targets for predators. The qualities that make them easy to herd and manage also make them easy prey. Primary predators are coyote, bears, mountain lions and dogs. In 1994, the last year for which these numbers are available, preda- tors killed over 500,000 head of sheep and lambs in the United States. This accounted for 42 percent of all sheep death losses. On the Paonia Ranger District in 2001 there were 171 kills by coyotes, 110 by bears and 27 died from poisonous plants.

Most producers try to minimize predator losses through a combination of animal husbandry and prevention techniques. The herder stays with the sheep to guard against predator attacks. All the herders use guard dogs. There are a number of breeds of guard dogs used in the United States Akbash, Komondor, Great Pyrenees and Anatolians. The most commonly used guard dog in western Colorado is the Turkish A $\mathrm{k} \mathrm{b}$ a $\mathrm{s} \mathrm{h}$. Generally there are 2 to 5 guard

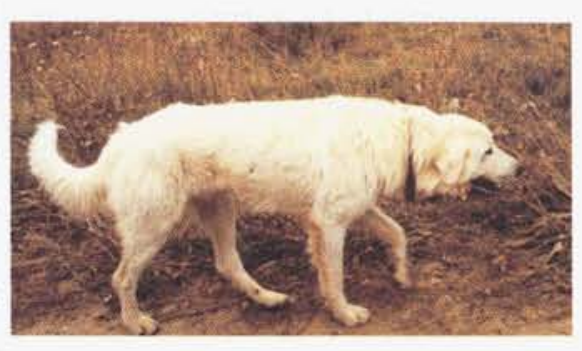
dogs with each band of sheep, depending on predator populations. These large white dogs stay with the sheep, all the time. They do not eliminate predation on the sheep but they reduce the losses significantly and provide a non-lethal deterrent.

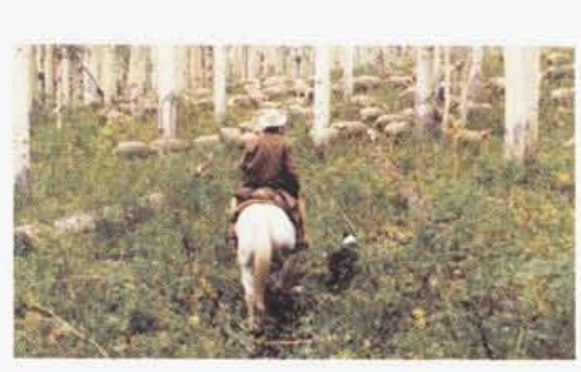

Vegetation Management Sheep are well suited to vegetation management. Their herding instincts and their selectivity when foraging make them excellent biological agents for influencing a plant community. Sheep are used in a variety of ways to accomplish vegetation objectives. Some of these include: controlling noxious weeds, improving growing conditions for conifers by reducing brush competition, improving forage conditions for cattle by reducing poisonous plant densities and improving habitat conditions for wildlife.

On the Paonia Ranger District, sheep are used to graze areas of tall larkspur prior to cattle grazing. This strategy has been used for over 20 years. Sheep graze pastures with high larkspur densities a week or so ahead of the cattle. They graze the lower 
leaves of the plants and knock down the stems of these 4 to 8 foot tall forbs. This reduces the chances that cattle will graze enough larkspur to get a lethal

dose of the

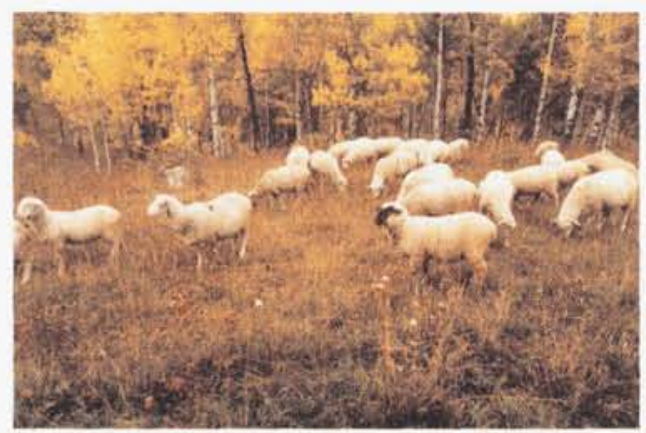

poisonous alkaloids that are found in the plant. This strategy provides much greater flexibility in developing cattle grazing rotations, which allows better management of the entire cattle allotment. It also allows different livestock producers to use the same area of land without having to construct fences.

We are beginning to use sheep grazing to reduce mulesear in areas with abnormally large populations of this native but generally unpalatable plant. The strategy involves grazing mulesear-dominated areas with a large number of animals for a short period of time when the plant is most palatable - just prior to flowering. This approach works with cattle and appears to be a promising technique with sheep as well.

\section{Conflicts}

As with many uses of the public lands, there are conflicts between domestic sheep and other uses. The most common involve recreation, wildlife and cattle.

Recreation conflicts generally involve backpackers and mountain bikers. These forest visitors may encounter a band of sheep with the associated herd and guard dogs. The recreationists may be confused by the presence of the sheep, intimidated by the sheep and or dogs or actually attacked by the guard dogs. These conflicts may be exacerbated if the recreationists have their own dogs with them.

These conflicts can all be resolved. Many ranger districts with sheep grazing post information posters at trail heads explaining why the sheep are on the national forest and how to handle encounters with guard dogs. Most ranchers do not place extremely aggressive guard dogs on public lands - the risk of a lawsuit is too great. If guard dog problems develop the Forest Service and the ranchers work to resolve or minimize the conflict.

Conflicts with domestic sheep and wildlife primarily involve bighorn sheep and predatory animals - coyotes, bears, and mountain lions. The conflicts with domestic sheep in Colorado primarily involve the transmission of diseases. Bighorn sheep are highly gregarious and prone to parasitic diseases such as lungworm. The specific effects of domestic grazing on bighorn sheep remains controversial but likely depends on the population size and proximity of the domestic sheep. In Colorado, management strategies involve trying to keep domestic sheep and bighorn sheep separate and maintain a 5-mile buffer zone.

Conflicts with predatory animals obviously involve the predators killing domestic sheep.

Some strategies for minimizing these conflicts have been referred to earlier in this paper - good herd management (moving the sheep often, limiting the time sheep use a bed-ground, etc.) to reduce attracting predators and the use of guard dogs. Herders also carry firearms and will use them to protect the sheep. Predators that are known to kill sheep are hunted down and eliminated by a professional trapper. The emphasis is on removing specific animals and not on broad-scale predator reductions. Predator control remains a controversial issue in domestic sheep grazing on public lands. However, for the most part predator populations continue to increase across Colorado.

Conflicts between sheep and cattle are mostly perceptual. Sheep and cattle tend to graze different plants so competition for forage is minimal. In fact, the two species can graze the same piece of ground. Dual-use grazing increases the potential for overgrazing, but with well planned grazing strategies and proper stocking the practice can be done successfully and beneficially.

Most conflicts involving sheep grazing on public lands can be resolved with proper management and improved understanding.

\section{Economics}

As with most agricultural operations in the United States today, the greatest uncertainty involves economic conditions. Many of the same trends that have affected all of American agriculture have occurred in the sheep industry in the West. Over the 
past 50 years agricultural outputs have increased as the level of inputs have remained constant or decreased. This increased productivity has been a major factor in a rancher's ability to stay in business, when the prices they receive are relatively low.

In the year 2000, the value of agricultural land averaged \$1,050 per acre. Agricultural land values have increased steadily across the United States since 1987. Land values in the 1970's were $\$ 150$ per acre, compared to 2000 this is a nearly $300 \%$ increase. At the same time overall prices for agricultural products have decreased. The price in 2001 for slaughter lambs was 79 cents per pound (\$78.91/ cwt.). Prices in 1970 were 88 cents per pound (\$27.43/cwt.) This represents a less than 200 percent increase over the same time period. The opening of U.S. markets to foreign producers, the continued increase in land values and the likely increase in labor and other production costs are all factors that will likely affect the economic viability of sheep production in the West.

\section{Sheep Fill A Niche}

Livestock production is a sustainable economic activity that provides many benefits to land and communities. Livestock provide food and fiber for people.

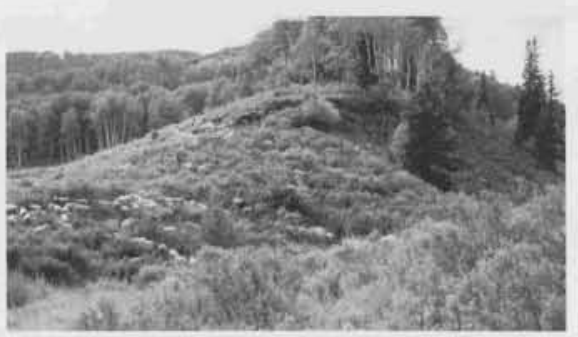
They also sup-

port other agricultural activities. They can use less productive land to produce valuable economic benefits. Sheep are well suited to many low-productivity areas in the western United States and to areas not well suited for cattle. These areas can be used to provide economic benefits while maintaining their natural state. Under proper management sheep grazing is ecologically sustainable. Our natural landscapes are becoming increasingly rare as human populations increase. Finally, sheep can be used as a management tool to maintain these areas in their most desirable condition. We believe the images shown in this article accurately depict contemporary sheep raising in the western United States. They represent a sharp contrast to the specter of "hooved locusts destroying the land"

\section{Trail Gulch on Muddy allotment 1949 and 2000}

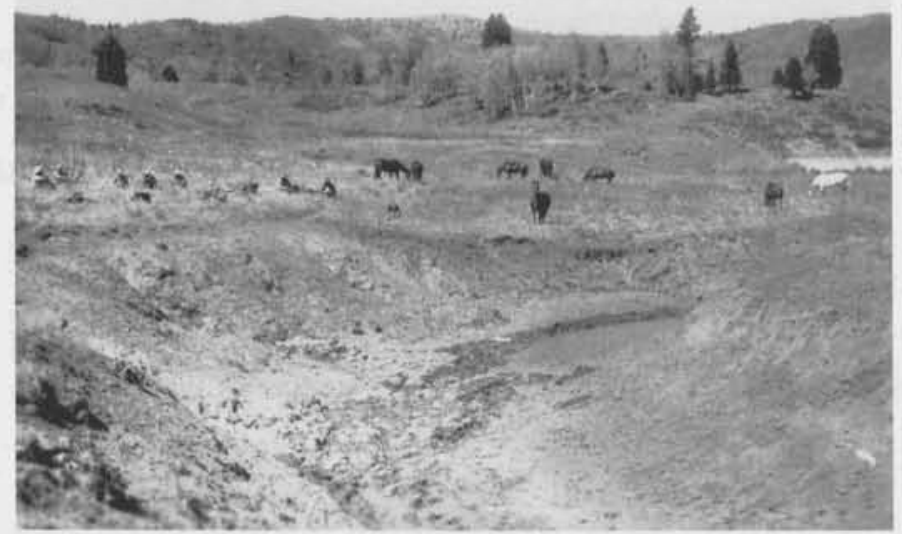

Photo by Arthur Cramer, 9-20-1949

Denver Public Library, Western History Collection

Allotment grazed season-long by 244 cow/calf pairs from June 1 to October 15, 1949. Caption on back of photograph noted "Stream channel cut-down, willows out, range poor to depleted. West Divide cattle allotment." Precipitation for the year was $110 \%$ of "average."

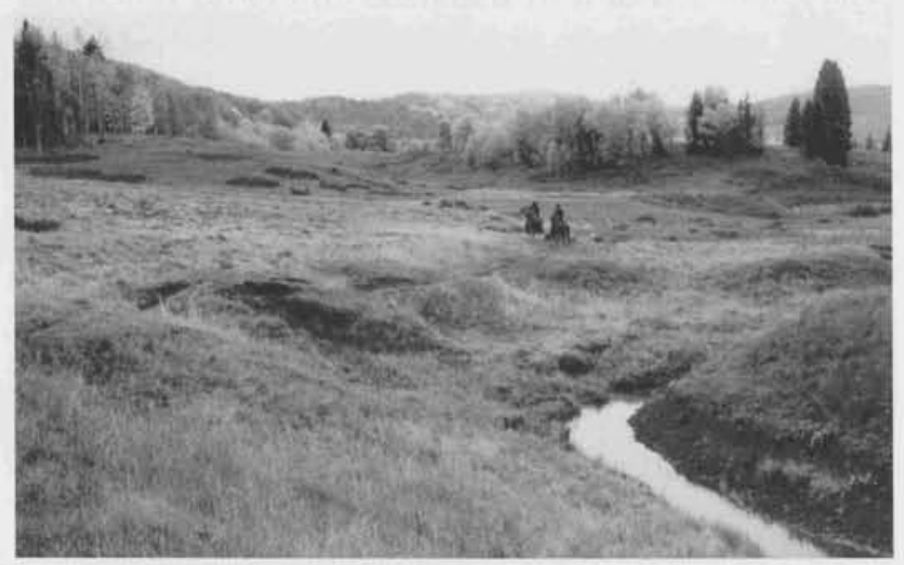

Photo by David Bradford, 9-20-2000

U.S. Forest Service Collection

This area added to Muddy Sheep allotment in 1950's. Site was grazed by 1,046 ewe/lamb sheep in mid-July, for ten days. Precipitation for 2000 was $80 \%$ of long-term average. Trail Gulch was once severely abused by improper cattle grazing. The area was incorporated into an adjacent sheep allotment. The site has recovered dramatically. Sheep tend to have less impact on riparian areas. 
Authors - Bradford and McConkey are Rangeland Management Specialists on the Paonia Ranger District, Gunnison National Forest; LeValley is Colorado State University livestock-range Extension Specialist for the TriRiver Area, Farmer, Allen, Allen and Sperry are sheep producers in Delta County, Colorado.

\section{References}

History of Agriculture in Colorado: A Chronological Record of Progress in the Development of General Farming, Livestock Production and Agricultural Education and Investigation, on the Western Border of the Great Plains and in the Mountains of Colorado, 1858 to 1926 by Alvin T. Steinel. Fort Collins, Colorado, State Agricultural College, 1926.
Saga of a Forest Ranger by Len Schoemaker. Boulder, Colorado, University of Colorado Press, 1958

Cow Trails along the North Fork by Wilson Rockwell. The Denver Westerners 1973 Brand Book, Volume XXIX, p. 372-395; Boulder, Colorado; Johnson Publishing Co., 1973

A Land Alone: Colorado's Western Slope by Duane Vandenbusche and Duane A. Smith. Boulder, Colorado, Pruett Publishing Company, 1981

"Bloody Grass: Western Colorado Range Wars, 1881-1934" by Diane Abraham. Journal of the Western Slope, Vol. 6, No. 2, Spring 1991.

American Sheep Industry website: www.sheepusa.org

USDA National Agricultural Statistics Service, Trends in U.S. Agriculture.

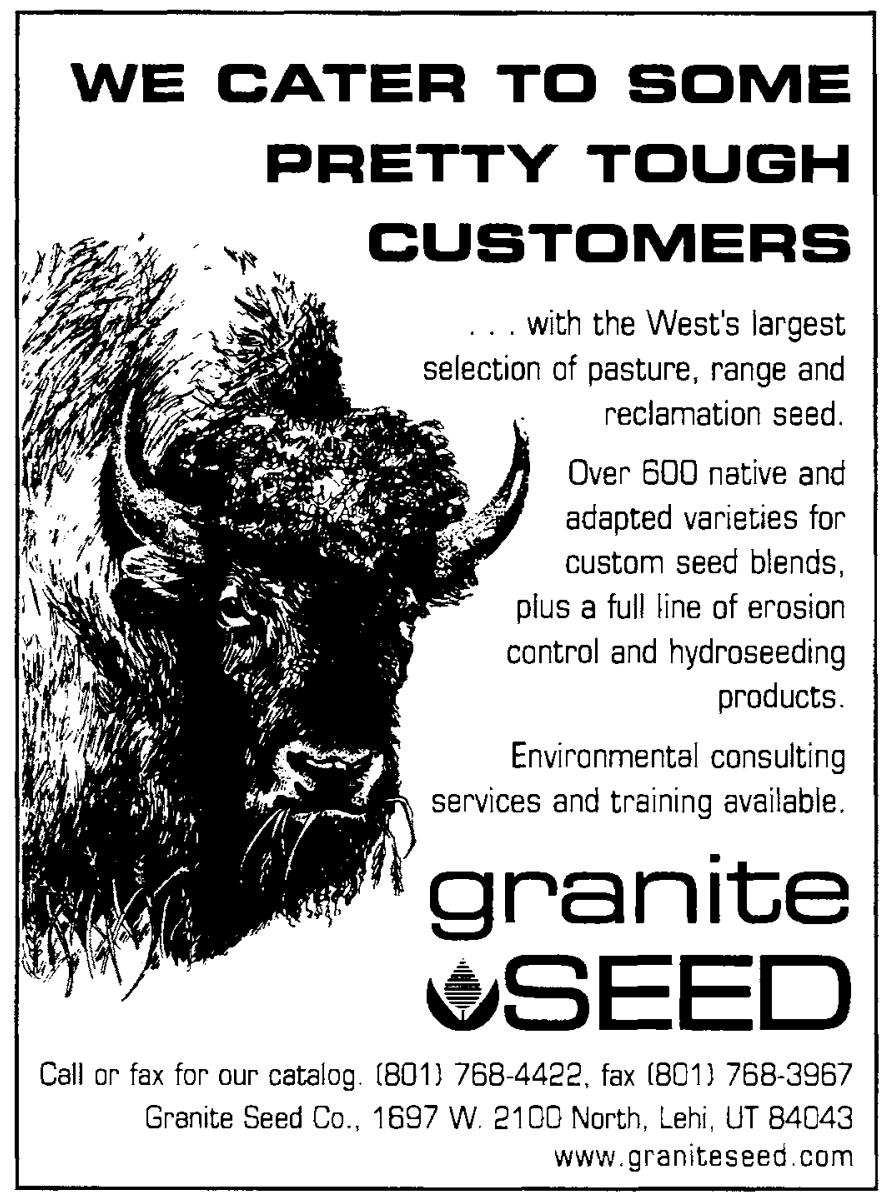

